GEOGRAFICKÝ ČASOPIS / GEOGRAPHICAL JOURNAL 71 (2019) 3, 227-240

DOI: https://doi.org/10.31577/geogrcas.2019.71.3.12

\title{
EXPLORING THE LINKS BETWEEN THE ETHNIC STRUCTURE AND THE DWELLINGS QUALITY IN THE ROMANIAN DANUBE VALLEY
}

\author{
Irena Mocanu*, Bianca Mitrică*, Mihaela Persu*, Nicoleta Damian** \\ * Institute of Geography, Romanian Academy, Human Geography and Regional Development Department, \\ 12 Dimitrie Racoviţă Str., sector 2, RO-023993 Bucharest, Romania, \\ mocanitai@yahoo.com,biancadumitrescu78@yahoo.com,persu_mihaela@yahoo.com \\ ** Institute of Geography, Romanian Academy, Environment and GIS Department, 12 Dimitrie Racoviţă Str., \\ sector 2, RO-023993 Bucharest, Romania; nicoleta_damian2002@yahoo.com
}

\begin{abstract}
Exploring the links between the ethnic structure and the dwelling quality in the Romanian Danube Valley

The Romanian sector of the Danube Valley covers a large area in which the life of resident communities is shaped by the river (1,075 km long). Exploring the links between the location of different ethnic minorities and the dwelling quality supposes to process and to map the statistical data provided by the National Institute of Statistics. Computing the final Dwelling Quality and Ethnic Diversity Indexes and mapping the secondary indexes offer the possibility to conclude that only two of the statistical variables assessing housing quality (dwellings connected to the water supply network and with a bathroom inside the house) show good statistical and territorial correlation with the share of Roma and Serbian minorities.
\end{abstract}

Key words: ethnic minorities, dwelling quality, Danube Valley, Romania

\section{INTRODUCTION}

The issues of home, housing, household, ethnic/racial groups and interrelations between dwelling and ethnicity represent a field of research for many human sciences. In their critical literature reviews dealing with such concepts, Cieraad (2010), Easthope (2004) and Mallet (2004) quoted the inter-disciplinary approaches published by Saunders (2010), Feld and Basso (1996), Rapport and Dawson (1998), Birdwell-Pheasant and Lawrence-Zúniga (1999), Annison (2000), Low and Lawrence-Zúniga (2003). Housing tenure is known to be related to demographic and economic factors (Boal 2002), but little is known about the effect of cultural factors, among them ethnicity. The character of ethnic milieu influences the place where people live (Lewis et al. 2004) and in terms of dwelling quality, the individual's, or the community's ethnicity shapes residential segregation (Charles 2003). It models how housing units and households are projected, equipped or maintained in good conditions (Oliver and Shapiro 1995 and Somerville and Sprigings 2005).

The territorial distribution of ethnic groups inside the housing scheme seems to follow two models: of constraint (or bounded choices) and of choice (or voluntary chosen) - Cashmore (2004), Varady (2008), McGarrigle and Kearns (2009) and McGarrigle (2010) - Fig. 1, part A. Giving the Romanian research into the relationship between the ethnic structure and housing, the theoretical approach is applied to the Romanian Danube Valley (Fig. 1, part B), where the various ethnic groups (different in terms of religion and ethnicity) have settled, in the course of history, in different places as a result of population shifts, often imposed by political, religious or economic factors. 


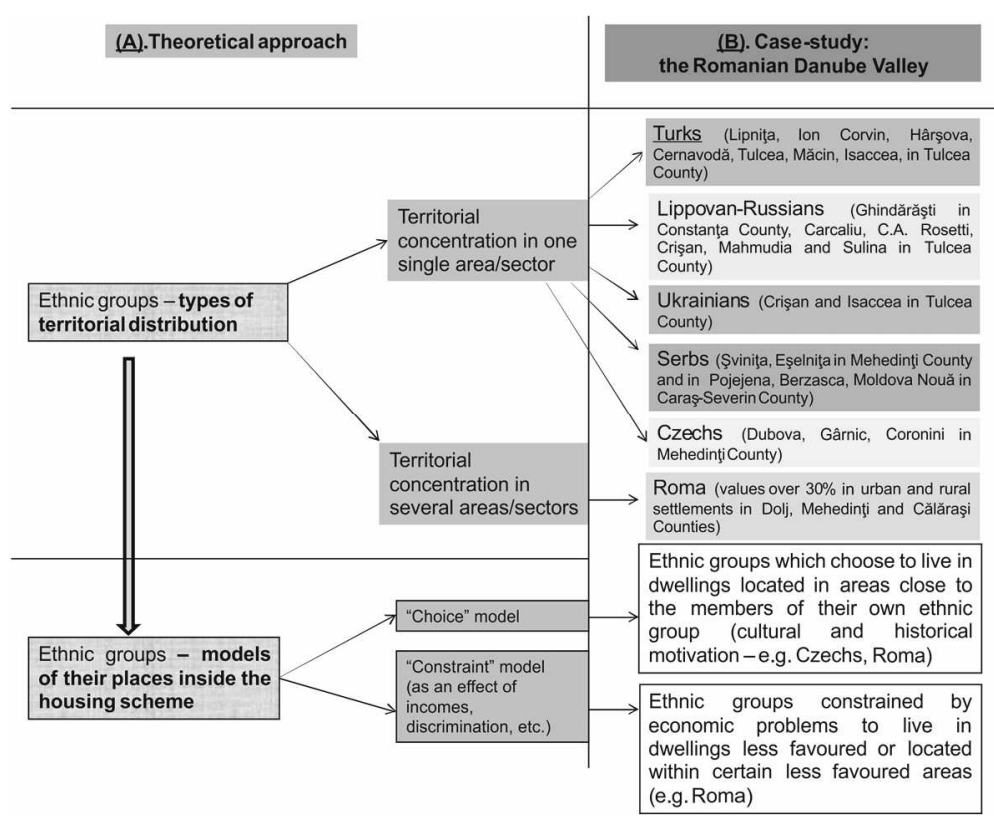

Fig. 1. Theoretical approaches of the relations between the ethnic groups' territorial distribution and the models of their places inside the housing scheme (A) and the application to the Romanian Danube Valley (B)

Sources: (A) - adapted from Boal ed. (2002) and Cashmore ed. (2004) and (B) - authors' compilation.

Romanian research into the relationship between the ethnic structure and housing is not that developed as elsewhere in the world. Majuru (2011) studied the built -up area as an indirect reflection of the social, cultural and historical milieus, which are, in its turn, directly influenced by it. Also, several Romanian academic studies on housing conditions in terms of detrimental, precarious features (e.g. Voicu 2005, Constantinescu et al. 2005, Berescu et al. 2006, Suditu and Vâlceanu 2013, Swinkels et al. 2014, Roşu et al. 2015, Ghiță et al. 2016, Teşliuc et al. 2016) deal with the ethnic-related causes of the negative housing situations. The issue of ethnic influence on housing quality was studied by Constantinescu et al. 2005, Micu 2009, Swinkels et al. 2014, Teşliuc et al. 2015 and Teşliuc et al. 2016), who pointed some negative aspects related to the settlements with higher percentage of Roma minority, different sanitary facilities and also to the theoretical and practical roles performed by specialised public institutions (Briciu 2016). Giving this picture, this paper attempts to enlarge the existing literature by analysing at a local territorial level (e.g. local administrative units - LAU), the relationships between the quality of rural/urban dwellings and the presence, on its territory, of different ethnic groups.

In view of the above, the present study concentrates on a specific research question: Are there any relationships between the quality of housing and the territorial concentration of ethnic groups in certain areas of the Romanian Danube Valley? 


\section{DATA SOURCES AND METHODOLOGY}

The study uses the database for LAU level, that is, the results of the Population and Housing Census in October 2011 and TEMPO Online, published by the National Institute of Statistics (2011a and 2011b). Statistical variables and indicators have been chosen in terms of the database available for the LAU level. Also, the examples identified in several works of sociology, urbanism, architecture and geography were sources of inspiration (Constantinescu et al. 2005, Vîrdol 2009, Vâlceanu and Tămârjan 2011, Vâlceanu and Zulaica 2012, Institute for the Protection and Security of the Citizen, ECJRC 2014, Swinkels et al. 2014 and Teşliuc et al. 2016).

The complex aspects of dwelling quality are discussed in the light of three secondary indexes (Mocanu et al. 2017) such as the Dwelling-Stock Index (DSI), the Dwelling Development Index (DDI) and the Dwelling Comfort Index (DCI).

The Ethnic Diversity Index (EDI) is based on the share of the minorities/total population.

The two indexes are mapped and two types of areas are delimited: 1) areas with high Ethnic Diversity Index and high Dwelling Quality Index values and 2) areas with high Ethnic Diversity Index and low Dwelling Quality Index values.

The links between the ethnic structure and the dwellings quality are revealed by the simple linear correlation coefficient $\mathrm{R}^{2}$. This enabled us to outline the situation of each minority in the study area and establish the rank of settlements in terms of their share of each minority/total population and the values of secondary indices (DDI, DCI and DSI) or of the final index of dwelling quality (DQI) - Fig. 2.

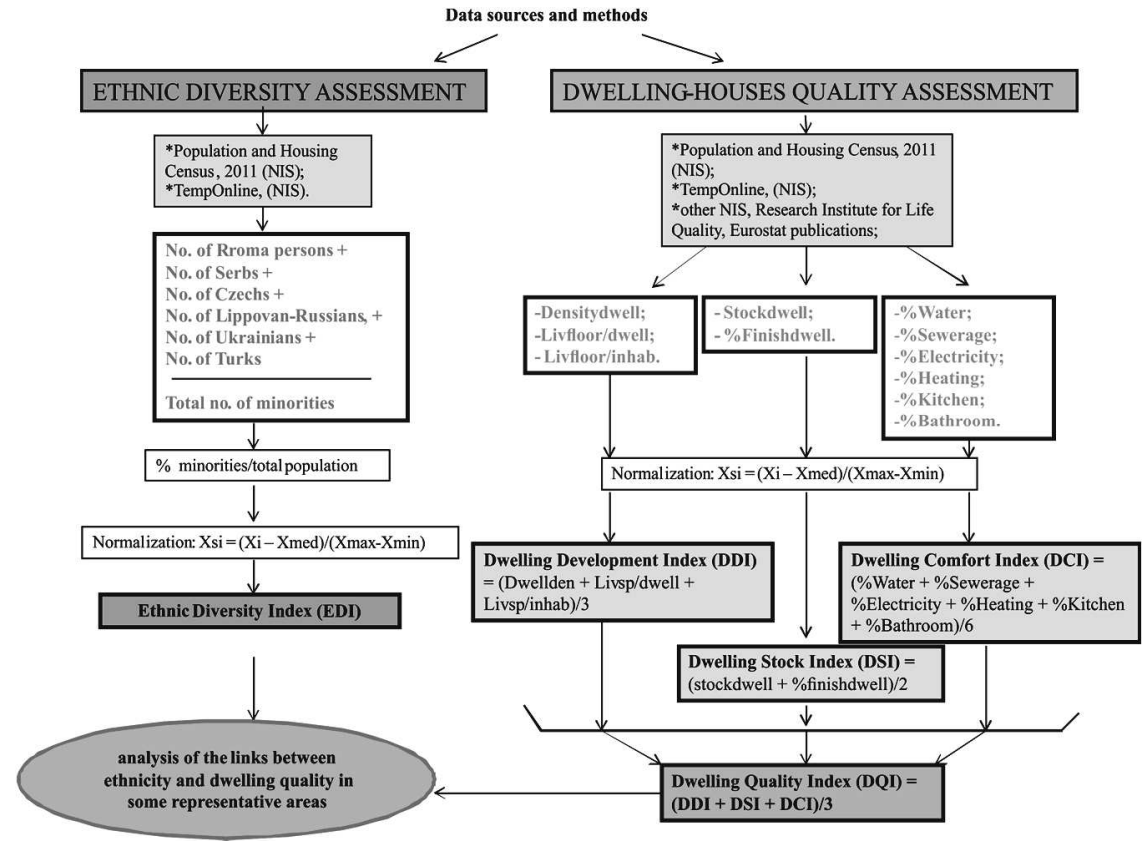

Fig. 2. Indexes design

Source: authors' compilation and Mocanu et al. (2017). 
In this paper, the Population and Housing Census 2011 (National Institute of Statistics 2011a) and TEMPO Online (National Institute of Statistics 2011b) represent the sources of data which were processed and mapped by the authors, as is shown in figures 4 and 5. Also, this paper use the notion of "ethnicity" as it is defined under the Population and Housing Census 2011 terms, definitions and provisions - "Ethnicity is a person's choice of belonging to a human group with common traits of civilization and culture through one or more of the characteristics of language, religion, common traditions and habits, lifestyle etc." (National Institute of Statistics 2011a) and it is declared freely and according to one's own opinion, without any constraint. The present study uses the term "dwelling" as defined in the methodology of statistical data collection for the October 2011 Population and Housing Census and in the Baze de date statistice data-base - "a dwelling is the built unit made up of one or more habitable rooms situated at the same floor of the building or at different floors, generally fitted with outhouses (kitchen, bathroom) or with other serving spaces, which is functionally independent and has a separate entrance from the staircase hall, yard or street and which has been built, transformed or arranged with a view to being used, in theory, by one household" (National Institute of Statistics 2011a and 2011b).

\section{STUDY-AREA: GENERAL SOCIO-ECONOMIC FEATURES AND ETHNIC DIVERSITY}

Our study-area is located in south Romania, the Romanian Danube Valley including parts of four Romanian development regions (West, South-West Oltenia, South Muntenia and South-East Dobrogea) and of twelve counties (Caraş-Severin, Mehedinţi, Dolj, Olt, Teleorman, Giurgiu, Călăraşi, Ialomiţa, Constanţa, Brăila, Galaţi and Tulcea).

In terms of demographic features, the Romanian Danube Valley encompasses 266 LAU (238 communes, and 28 towns, Fig. 3) with a total population of 1.7 million inhabitants (2016), out of which $42 \%$ is rural and $58 \%$ is urban.

Most Danubian towns (19) fall into the small-size category (under 20,000 inhabitants, the smallest is Şegarcea, Dolj County, which records only 3,657 inhabitants). The biggest towns with over 100,000 inhabitants are Brăila $(210,699$ inhabitans) and Galaţi (304,610 inhabitans). The population of the rural area goes from only almost 550 inhabitants in rural settlements of Tulcea County (which encompasses the Danube Delta, a territory less favourable to the development of settlements) and almost 10,500 inhabitants in some rural LAU of Dolj County (Mitrică et al. 2016).

In terms of historic and socio-economic general features, during the three distinct periods in the evolution of the area's economy $(1829-1948$, when the Danube Valley functioned as Romania's outlet; 1948 - 1989, when the Danube "industrial belt" was established, 1989 - 2011, the post-communist period), the study-area shows a socio-economic decline of several important large urban centres and also of middle and small towns (Mitrică and Popescu 2017). Looking at the socio-economic development in rural areas, the Romanian Danube Valley was, and still is experiencing uneven development (Mocanu et al. 2015). These different and complex historical, socio-economic and cultural contexts are reflected by the almost 746,000 dwelling-units located within the Romanian Danube Valley $(10 \%$ of the total number of dwellings in Romania). The natural environment is mirrored 
especially in dwellings from rural areas, where building materials and the type of construction differ with the geographical region and the cultural tradition (Mocanu et al. 2017).

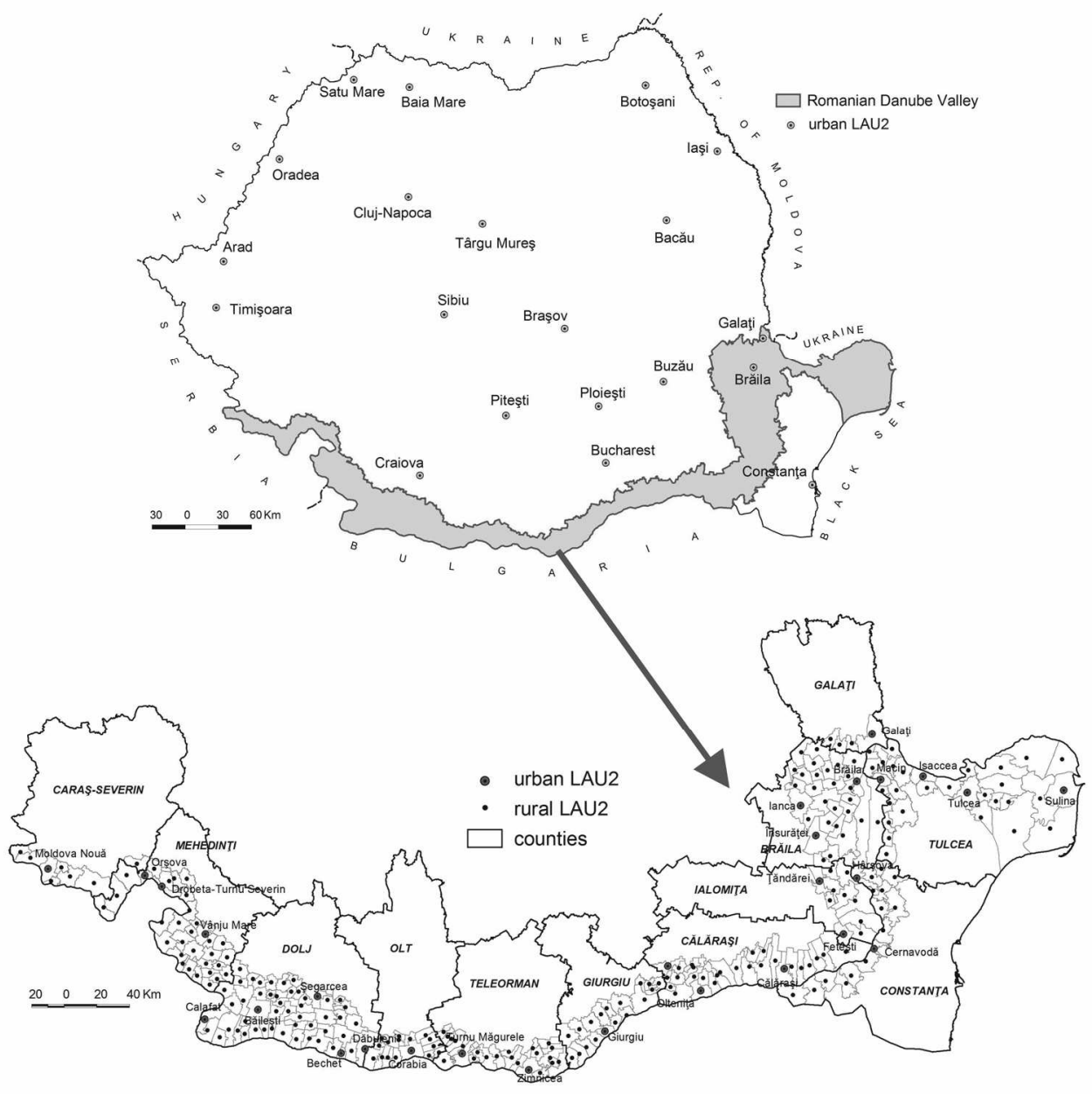

Fig. 3. The study-area

The Romanian Danube Valley is an area with a long history in terms of cohabitation of the Romanian majority with others ethnic minorities groups. Despite the fact that in the Romanian Danube Valley the majority population is represented by Romanians $(87.9 \%$ of total population within studied area), there are many other ethnic minorities groups such as the Roma (3.8\%), the Lippovan-Russians $(0.6 \%)$, Serbs $(0.3 \%)$, Turks $(0.2 \%)$, Ukrainians and Czechs (with $0.1 \%$ each).

The presence of the Roma population within the territory of present-day Romania dates back to the 14th century. The curent territorial distribution shows some agglomerations in the counties of Dolj, Mehedinţi and Călăraşi. According to the 2011 Population Census data, this minority represented $3.8 \%$ at that time in the 
study-area, with the highest values (45.7\% in a rural settlement from Dolj County) (Fig. 4). Values of over 30\% were recorded in nine rural LAU and in two urban LAU (Bechet and Budeşti).

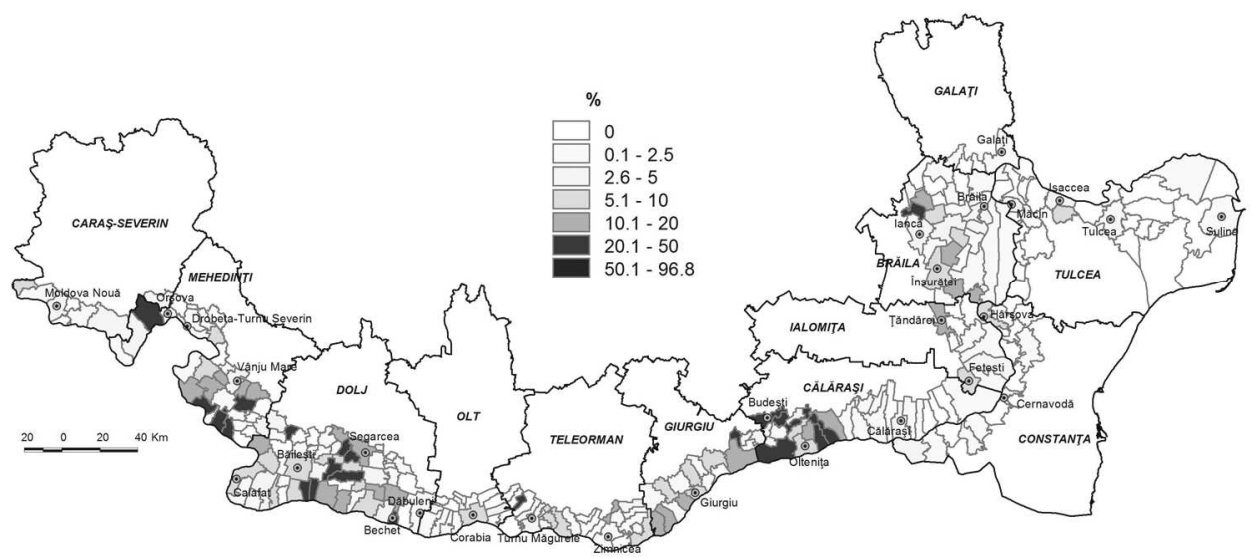

Fig. 4. The territorial distribution of the Roma minority

The Serbs' migration onto the current territory of Romania took place between the end of the 14th century and the end of the 18th century (Union of Serbs from Romania 2018). They targeted the Iron Gate Defile. The Serbian minority represents $0.3 \%$ of total population in the study-area but in the west of the Romanian Danube Valley, their shares are higher (90.3\% in Şviniţa, Caraş-Severin County). They hold a higher share in Socol (50.4\%), Pojejena (45.8\%), Berzasca $(20.8 \%)$ and Moldova Nouă Town (11.2\%) - Fig. 5 .

Starting with the 1820 s the Czechs were among the last populations which colonised, during three main stages (1823, 1827 and 1862), in the Banat region during the rule of the Habsburg Empire (Embassy of the Czech Republic in Bucharest 2018). Nowadays, the Czechs register a high share in the total population in Dubova (34.4\%) and Gârnic (23.2\%) - Fig. 5. In southern Banat, the villages with a Czech population surrounded by Serbian and Romanian populations, are a unique cultural phenomenon. Due to their isolated geographical location, the Czech language, the dwellings, households and traditional way of cultivating the land have been perfectly preserved.

The Lippovan-Russians are descendants of the Orthodox Russian Church of the Old-Rite believers, the first documentary attests to their presence in present-day Romania dating back to the years 1724-1740 (Ipatiov 2002). In Dobrogea (a region that belonged in the first half of the 18th century to the Ottoman Empire), the Cossacks from the Don region settled in the Danube Delta (Gârlan 2011). According to estimates, Russians and Lippovans together amount to 9,700 people. They live grouped mostly in Tulcea County, in the Danube Delta villages. Large numbers are registered also in the counties of Constanţa, Brăila and Ialomiţa, with the highest percentages in Ghindăreşti $(94.5 \%)$ - Fig. 5 .

The Ukrainians came to the Danube Delta at the end of the 18th century, after the Russian Queen Catherine II had destroyed the political, administrative and mili- 


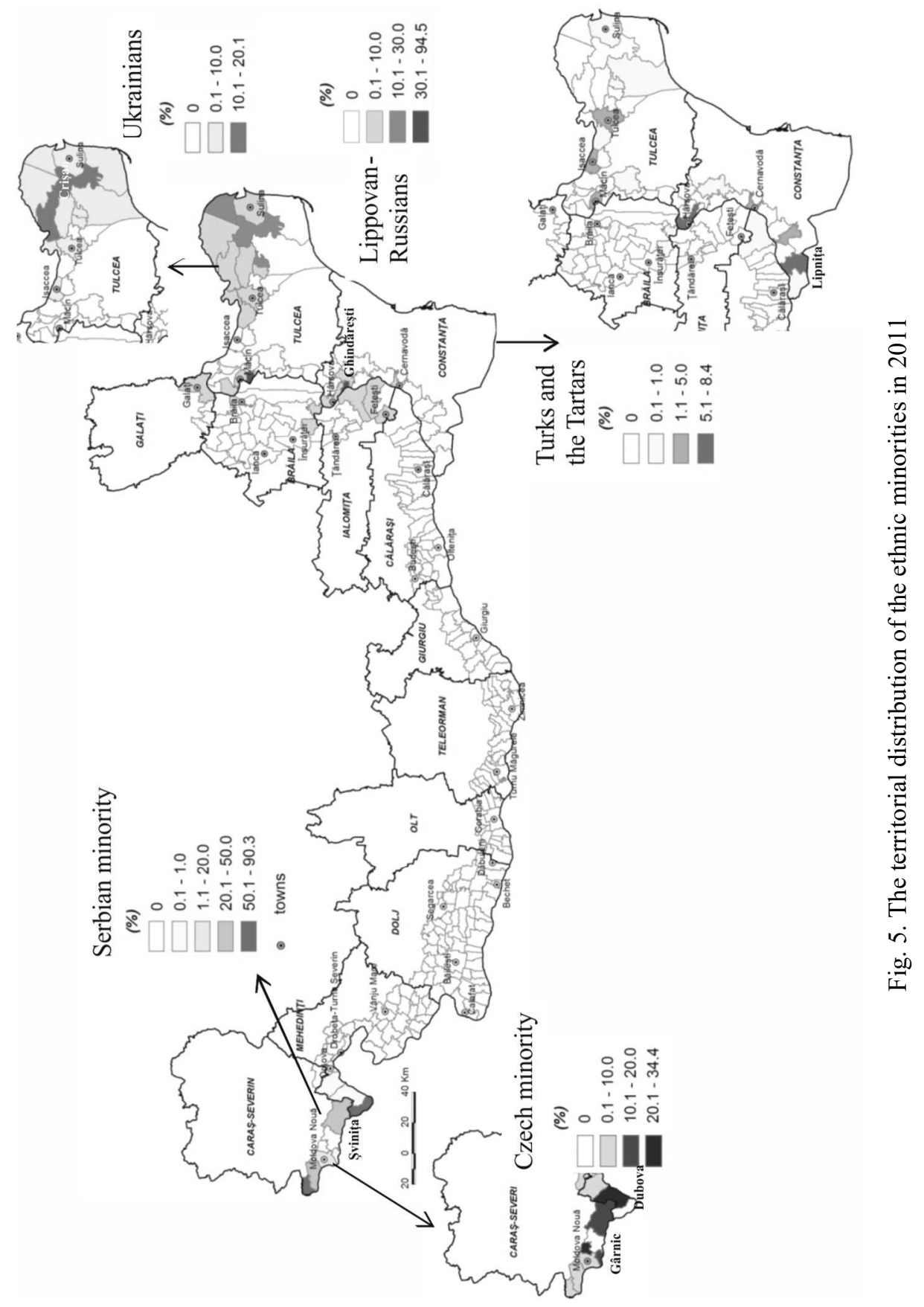


tary center of the Zaporojan Cossacks, located in the steppes of north of the Black Sea (Embassy of the Ukraina in Romania 2018). In those times, for fear of being exterminated, over 8,000 Cossack Ukrainians settled in the Danube Delta. They are Orthodox of the Old Rite, being called "haholi" by the locals to distinguish them from their Lippovan neighbours. Nowadays, they represent $20.1 \%$ of total population of the Crişan rural settlement (Tulcea County) - Fig. 5.

The presence of the Turkish minority on Romanian territory dates back to the second half of the 15th century, when the Ottoman Empire focussed its attention on the Black Sea Basin. The presence of the Turks in the present-day Romanian has lasted, with some interruptions, for almost 400 years (the 15th-19th centuries). The Tartars settled in these places in several successive stages, starting with the 13th century. After the Crimean War $(1853$ - 1856), under pressure from the Russians, the Tartar communities from the Crimea occupied central and southern Dobrogea, being engaged in agriculture, horse-breeding, transport and trade (Mehmed 1978; Mehmet 1994). Over $80 \%$ (3,691 inh.) live in the counties of Constanţa, Tulcea and Brăila, large percentages live in Lipniţa (6.6\%) and in the towns of Hârşova $(8.5 \%)$, Cernavodă $(2.8 \%)$, Măcin $(2.5 \%)$, Isaccea $(1.8 \%)$ and Tulcea $(1.2 \%)$ Fig. 5.

All these historic and spatial considerations on ethnic minorities living within the Romanian Danube Valley, reveal that the links between dwelling quality and ethnic structure in certain rural or urban areas have had time to establish and stabilize. Thus, nowadays the differences between the localities where the share of one or another ethnic minority is higher than in the other settlements (with a Romanian majority), and this last category of settlements, are visible.

\section{RESULTS AND DISCUSSIONS}

In the study-area, the share of minorities of the total population was $12 \%$ (in 2011), compared to the national value which was $16.6 \%$.

The main areas with a high ethnic diversity index (EDI) are as follows:

1) Iron Gate (in Mehedinţi and Caraş-Severin counties, where live Czechs and Serbs);

2) the Danube lake area (Călăraşi, Ialomiţa and Brăila counties), Oltenia Plain (Mehedinţi and Dolj counties), the Argeş River-Danube junction area (Budeşti and Olteniţa în Giurgiu County, where Roma live);

3) the LAU located on the Dobrogean side of the Valley (Turks in Hârşova and Măcin towns);

4) the Danube Delta (Tulcea County where Lippovan-Russians and Turks live) (Fig. 6).

Several scientific studies and researches (Micu 2009, Niţă 2009, Anan et al. 2014, Anton et al. 2014, Teşliuc et al. 2015 and Teşliuc et al. 2016) show that the Roma minority is excluded from the housing market (Anton et al. 2014, Ministry of Labour, Family, Social Protection and Elderly 2015) and that its housing conditions are more precarious than those of the majority population (Romanian Government 2016). The calculations by using the simple linear correlation coefficients $R^{2}$, enabled us to outline the situation of the Roma population in the study area and establish the rank of settlements in terms of their share of Roma persons/total population and the values of secondary indices or of the final index in terms of dwell- 
ing quality. The values obtained were pretty low, which actually shows that no correlation between the variables referred to does exist. An explanation would be that the Roma minority is spread out in the Danubian settlements. Also, the differences in housing quality exist in one and the same locality (some could be poor, others rich, hence a distinctively different housing quality at a local level). In the study area, 32 villages have marginalised areas, where over $20 \%$ of the total population of Roma origin live (Teşliuc et al. 2016). The analysis at the level of LAU with the highest shares of Roma (over 30\% in Dolj, Mehedinţi and Călăraşi counties, and even more than $40 \%$ in Cătane and Negoi) reveals a higher linear correlation (between ethnic structure and DQI, $\mathrm{R}^{2}=0.630$ ).

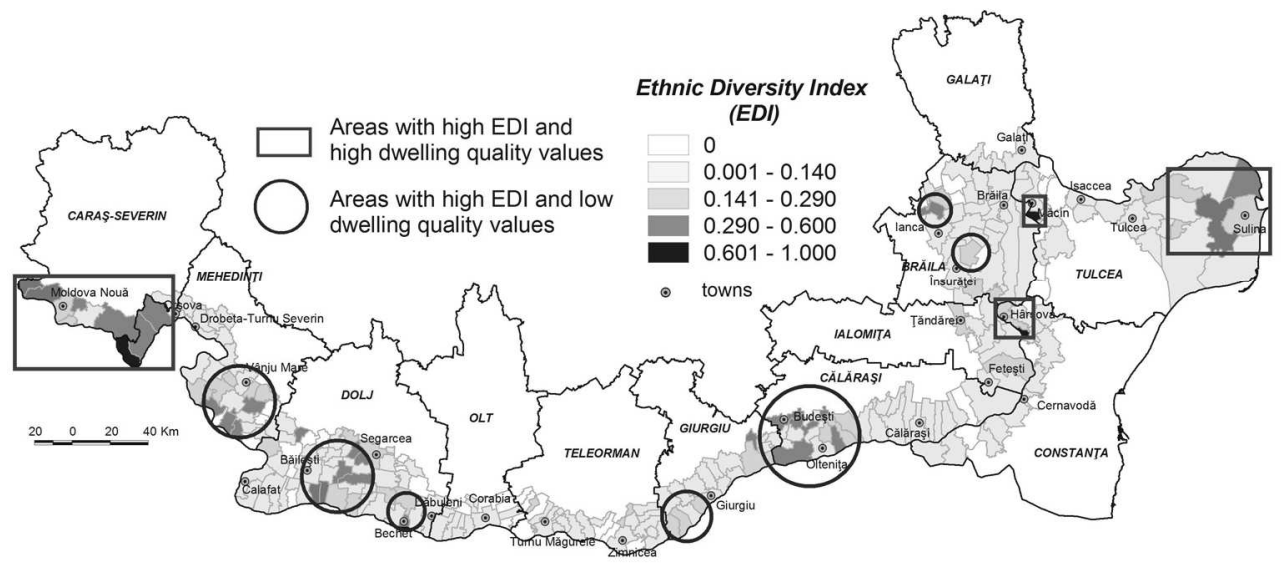

Fig. 6. The territorial distribution of the Ethnic Diversity Index (EDI) and the Dwelling Quality Index (DQI)

- Dwelling Stock Index (DSI) values are low, because there are rather few dwellings, most of them uncompleted in 2011 (a cause from what might be the precarious economic situation);

- Dwelling Development Index (DDI) values show great variations in terms of dwelling numbers. Among the Danubian LAU with an over 25\% Roma population, two types of settlements were identified: those with high dwelling densities; and with low dwelling densities. Living space/dwelling values are quite suggestive for the living standard of Roma communities in the Danubian localities. There are rural LAU in which the Roma represent $20 \%-30 \%$ and the living space/dwelling is high $\left(67.7-53.0 \mathrm{~m}^{2}\right)$. However, there are numerous localities with a high share of Roma/total population, but with a limited living space $\left(33-35 \mathrm{~m}^{2}\right)$. The same situations and examples are applicable to the living space/dwelling indicator.

In some settlements with high shares of a Roma population, the values of indicators used to assess the Dwelling Comfort Index (DCI) are null or very low. However, there are rural LAU with a numerous Roma population, scoring high indoor kitchen and bathroom values / total dwellings; noteworthy, as the share of the Roma/total population keeps growing, these indicator values are dropping (e.g. Chiselet, Călăraşi County by $19.8 \%$ Roma and $80 \%$ indoor kitchen, Bechet and Dolj County by $32.6 \%$ and $56 \%$, respectively). 
All in all, out study meets the typology of settlements with over $20 \%$ Roma inhabitants/total population which emerged from other scientific papers (e.g. Constantinescu et al. 2005) - settlements in which the Roma living standard and financial resources (from undeclared sources) allows them to live in large, high-comfort dwellings; - settlements in which they live in earthen huts with a very small onebed room(s), without any comfort at all (water, sewerage system, etc.).

As regards the Serbian minority, the results obtained with the correlation between ethnic structure and DSI $\left(\mathrm{R}^{2}=0.660\right)$ and between ethnic structure and DQI $\left(\mathrm{R}^{2}=0.503\right)$ show a medium degree of determination in both cases. The highest $\mathrm{R}^{2}$ value $(0.750)$ was yielded by correlating the ethnic structure with $\%$ of dwellings benefiting from indoor kitchen/total dwellings. As far as the DSI is concerned, the settlements with a Serbian population are not outstanding in the hierarchy of the whole study-area. The values of DDI in those settlements with a Serbian population vary from 0.310 (Sviniţa) and 0.552 (Pojejena). High living space values/ dwelling $\left(60.4 \mathrm{~m}^{2}\right)$ and the living space/inhabitant are recorded in the communes of Pojejena, Socol and Berzeasca.

The simple linear correlation indicator $\left(\mathrm{R}^{2}\right)$ coefficients of the Czech minority indicate no correlation between variables does exist. This result could be explained by the low proportion of this ethnic minority, besides, there is a mix of Czechs, Roma and Serbs.

Just like in the other cases, the results of calculating the simple linear correlation $\left(\mathrm{R}^{2}\right)$ coefficients for the Lippovan-Russians indicate no correlation. Analysing the communes with high proportions of this ethnic group in total population shows the following facts:

- Carcaliu (over 84\% Lippovan-Russians of total population in this rural LAU) ranks first in terms of DSI and DDI. There are 1,632 dwellings $(0.4 \%$ recently commissioned) with 2,457 dwellers. The Development Strategy of Carcaliu Commune mentions the reasons behind the increasing number of dwellings, despite an ageing population, namely, the money sent home by people working abroad. Therefore, it has nothing to do with the ethnic structure of the local population (Carcaliu Commune Hall 2013).

- although the analysed indicator values do not reflect the high dwelling quality of Lippovan-Russians, their owners feel comfortable due to the presence of traditional elements, e.g. "lejanka" (a place of rest and sleep near the chimney) and "bania" (a bath-room built outside the house).

\section{CONCLUSIONS}

Two of the statistical variables assessing housing quality show a good territorial correlation with the location of the different ethnic minorities:

- low shares of dwellings connected to the water supply network and with a bathroom inside the house, correlate with the high percentage of Roma minority;

- a high percentage of houses connected to the water supply network correlates with a high percentages of Serbs in the Danube Defile, and with the LippovanRussians and the Turks in the Danube Delta. So, for answering the research question, we mention that in certain small areas there exist territorial and statistical correlations between two indicators (dwellings connected to the water supply network 
and with a bathroom inside the house) and the territorial concentration of ethnic groups (Roma and Serbs).

The Romanian Danube Valley represents a large area in which the ethnic diversity is the outcome of various historical influences and confluences and several future research directions should focus on study-cases able to highlight the territorial relationships between ethnic structure and dwelling quality at micro-scale. At this territorial level the actions happen and solutions are more easily identified and applied, especially when the local reality is quite complex (e.g. the cases in which the Roma minority holds an important share of total population and it is associated with both high quality and low quality dwelling stock).

The present study has been carried out under the Romanian Academy's priority research projects on "The geographical study of the Romanian Danube Valley" and "Geographical Studies on the ethnic structure dynamics in Romania after 1990”, co-ordinated by the Institute of Geography. All the authors have equally contributed to this paper.

\section{REFERENCES}

ANNISON, J. E. (2000). Towards a clearer understanding of the meaning of "home". Journal of Intellectual \& Development Disability, 25, 251-262.

ANAN, K., KARACSONY, S., ANTON, S., BALICA, M., BOTONOGU, F., CATANA, A., DAN, A., DANCHEV, P., FARCASANU, D., FERRE, C., FLORESCU, R., GRIGORAS, V., IONITA, S., IVASIUC, A., KITS, B., KULLMAN, A., DE LAAT, J., MAGHERU, M., MATHEMA, A., MIHALACHE, C., MOARCAS, M., OFITERU, L., ROKX, C., ROSTAS, I., STANCULESCU, M. S., SWINKELS, R., TAN, L., THAPA, D., WEBER, M. (2014). Achieving Roma inclusion in Romania: what does it take? (Vol. 2). Final report. Washington D.C.: World Bank Group, [Online]. Available: http:// documents.worldbank.org/curated/en/2014/02/19362999/achieving-romainclusionromania-take-vol-2-2-final-report [accessed 15 October 2018].

ANTON, S., BALICA, M., BOTONOGOU, F., CATANA, A., DAN, A., DANCHEV, P., FĂRCÂŞANU, D., FERRE, C., FLORESCU, R., GRIGORAŞ, V., IONIȚĂ, S., IVASIUC, A., KITS, B., KULLMAN, A., DE LAAT, J., MAGHERU, M. MATHEMA, A. MIHALACHE, C., MOARCAŞ, M., OFIŢERU, L., ROSTAŞ, I., ROKX, C., STĂNCULESCU, M., SWINKELS, R. TAN, L. THAPA, D., WEBER, M. (2014). Diagnostics and policy advice for supporting Roma inclusion in Romania. Washington, DC: World Bank Group, [Online], Available: http://documents.worldbank.org/curated/ en/599081468094457693/Diagnostics-and-policy-advice-for-supporting-Romainclusion-in-Romania [accessed 12 Septemberber 2018].

BERESCU, C., CELAC, M., CIOBANU, O., MANOLACHE, C. (2006). Locuirea şi sărăcia extremă. Cazul romilor. Bucuresti (Edit. Universitară Ion Mincu).

BIRDWELL-PHEASANT, D., LAWRENCE-ZÚNIGA, D. (1999). House life: space, place and family in Europe. Oxford (Berg).

BOAL, W. F., ed. (2002). Ethnicity and housing: accommodating differences. Aldershot (Ashgate).

BRICIU, C. (2016), Politici sociale de locuire. Calitatea Vieţii, 27, 42-62.

CARCALIU COMMUNE HALL (2013). Strategia de dezvoltare a comunei Carcaliu, jud. Tulcea. Delta regioplan-planificarea strategică participativă a dezvoltării regionale rurale in judeţul Tulcea, [Online]. Available: http://www.paginadestart.com/comon/ resurse/carcaliu/Strategia de dezvoltare carcaliu.pdf [accessed December 2018].

CASHMORE, E., ed. (2004). Encyclopedia of race and ethnic studies. London (Routledge).

CHARLES, C. Z. (2003). The dynamics of racial residential segregation. Annual Review of Sociology, 29, 167-207. 
CIERAAD, I. (2010). Homes from home: memories and projections. Home Cultures - The Journal of Archiecture, Designe and Domestic Space, 7, 85-102.

GHIȚĀ, A., DAMIAN, A., TODERITǍ, A., ALBIŞTEANU, R., POPESCU, R. (2016). Locuirea socială în București între lege și realitate, Centrul pentru Dezvoltare Urbană și Teritorială, [Online]. Available: http://www.cdut.ro/library/main/ [accessed 12 September 2018].

CONSTANTINESCU, M., NITULESCU, D., BAJENARU, C. (2005). Zone precare de locuire în spaţiul urban. Calitatea Vieţii, 16, 65-85.

EASTHOPE, H. (2004). A place called home. Journal Housing, Theory and Society, 21, 128-138.

EMBASSY OF THE CZECH REPUBLIC IN BUCHAREST (2018). Comunitatea ceha din Banat: trecut şi present, [Online]. Available: https://www.mzv.cz/bucharest/ro/ cehii din romania/index 1.html [accessed Octomber 2018].

EMBASSY ŌF THE UKRAIINA IN ROMANIA (2018). Ucrainenii în România, [Online]. Available: https://romania.mfa.gov.ua/ro/ukraine-ro/ukrainians-in-ro [accessed December 2018].

FELD, S., BASSO, K., eds. (1996). Senses of place. New Mexico (School of American Research Press).

GÂRLAN, M. (2011). Metodologia cercetării etnopsihologice. Iași (Edit. Lumen).

INSTITUTE FOR THE PROTECTION AND SECURITY OF THE CITIZEN, EUROPEAN COMMISSION'S JOINT RESEARCH CENTRE (2014). Millennium development goals dashboard, [Online]. Available: http://esl.jrc.ec. europa.eu/envind/un meths/ UN ME049.htm [accessed 12 Septemberber 2018].

IPATIŌV, F. (2002). Ruşii lipoveni din România: studiu de geografie umană. Cluj Napoca (Presa Universitară Clujeană).

LEWIS, A., KRYSAN, M., COLLINS, S., EDWARDS, K., WARD, G. (2004). Institutional patterns and transformations: race and ethnicity in housing, education, labour markets, religion and criminal justice, In Krysan, M., Lewis, A., eds. The changing terrain of race and ethnicity. New York (The Russel Sage Foundation), pp. 67-122.

LOW, S., LAWRENCE-ZÚNIGA, D., eds. (2003). The anthropology of space and place: locating culture. Malden (Blackwell).

MAJURU. A. (2011). Rolul comunicării în relaţia populaţie majoritară-populaţie minoritară Studiu de caz: Relaţia dintre români şi ruşii-lipoveni din Mahmudia, [Online]. Available: http://www.e-antropolog.ro/2011/05/rolul-comunicarii-in-relatia-populatiemajoritara-populatie-minoritara-2/ [accessed November 2018].

MALLET, S. (2004). Understanding home: a critical review of the literature. The Sociological Review, 52, 62-89.

Mc GARRIGLE, J. (2010). Understanding processes of ethnic concentration and dispersal: South Asian residential preferences in Glasgow. Amsterdam (Amsterdam University Press).

Mc GARRIGLE, J., KEARNS, A. (2009). Living apart? Place, identity and South Asian residential choice. Housing Studies, 24, 451-475.

MEHMED, M. A. (1978). Istoria turcilor. Bucureşti (Edit. Ştiinţifică şi Enciclopedică).

MEHMET, A. E. (1994). Din istoria turcilor dobrogeni. Bucureşti (Edit. Kriterion).

MICU, J. (2009). Integrarea socială a rromilor, Etnosfera, 1, 11-24, [Online]. Available: http://www.etnosfera.ro/pdf/2009/1/02.pdf [accessed Octomber 2018].

MINISTRY OF LABOUR, FAMILY, SOCIAL PROTECTION AND ELDERLY (2015). Strategia națională privind incluziunea socială și reducerea sărăciei, [Online]. Available: http://www. mmuncii.ro/j33/images/Documente/Familie/2015-DPS/2015-sn-isrs.pdf [accessed December 2018].

MOCANU, I., MITRICĂ, B., VÂRDOL, A., ŞERBAN, P. (2015), Territorial patterns of socioeconomic development in the Romanian Danube Valley. Forum geografic. Studii şi cercetări de geografie şi protecţia mediului, 15, 164-177. 
MOCANU, I., MITRICA, B., DAMIAN, N., PERSU, M. (2017). The quality of dwellings in the Romanian Danube Valley (2011). Human Geographies - Journal of Studies and Research in Human Geography, 11, 95-109. DOI:1 10.5719/hgeo.2017. 11.6.

MITRICĂ, B., DAMIAN, N., MOCANU, I., ŞERBAN, P., SĂGEATĂ, R. (2016). Technical-urbanistic infrastructure in the Romanian Danube Valley. Urban vs. Rural territorial disparities. Geographica Pannonica, 20, 242-253.

MITRICĂ, B., POPESCU, C. (2017). The economy of the Romanian Danube Valley - evolution and trends, în vol. Lower Danube - Approaches to Macroregional Sustainability, 150-165.

NATIONAL INSTITUTE OF STATISTICS (2011a). Population and housing census 2011, [Online]. Available: http://www.recensamantromania.ro/rezultate-2/ [accessed 12 July 2018].

NATIONAL INSTITUTE OF STATISTICS (2011b). Baze de date statistice,[Online]. Available: http://statistici.insse.ro:8077/tempo-online/\#/pages/tables/insse-table [accessed 5 July 2018].

NIŢÂ, D. L. (2009). Romania RAXEN National focal point thematic study housing conditions of Roma and Travellers, [Online]. Available: https://fra.europa.eu/sites/default/ files/fra uploads/591-RAXEN-Roma\%20Housing-Romania en.pdf [accessed 5 July 2018].

OLIVER, M. L, SHAPIRO, T. M. (1995). Black wealth/white wealth. New York (Routledge).

RAPPORT N., DAWSON A. (1998). Migrants of identity: perceptions of home in a world of movement. Oxford (Berg).

ROMANIAN GOVERNMENT (2016). Pachetul Național Anti-sărăcie, [Online]. Available: http://gov.ro/fisiere/stiri fisiere/16-02-18-06-29-39160217 Pachet integrat pentru combaterea saraciei.pdf [accessed December 2018].

ROŞU, L., BLĂGEANU, A. (2013). Calitatea locuirii în profil teritorial - factor și rezultat al dezvoltării teritoriale. Program ESPON Evaluarea decalajelor teritoriale prin indicatori de dezvoltare comunitară, Iaşi.

ROŞU, L., CORODESCU, E., BLĂGEANU, A. (2015). Does geographical location matter? Assessing spatial patterns in perceived quality of life in European cities. European Journal of Geography, 2, 15-34.

SAUNDERS, P. (2010). The meaning of 'home' in contemporary English culture. Journal Housing Studies, 4, 177-192.

SOMERVILlE, P., SPRIGINGS, N., eds. (2005). Housing and social policy. Contemporary Themes and Critical Perspectives. London (Routledge).

SUDITU, B., VÂLCEANU, D. (2013). Informal settlements and squatting in Romania: socio-spatial patterns and typologies. Human Geographies - Journal of Studies and Research in Human Geography, 7, 65-75.

SWINKELS, R., STĂNCULESCU, M. S., ANTON, S., KOO, B., MAN, T., MOLDOVAN, C. (2014). The atlas of urban marginalized areas in Romania. Project Elaboration of Integration Strategies for Urban Poor and Disadvantaged Communities. Banca Mondială, București, [Online]. Available: http://backend.elard.eu/uploads/wb-project-in -ro/atlas 24april en.pdf [accessed September 2018].

TEȘLIUC, E. E., GRIḠORAȘ, V., STANCULESCU, M. S. (2015). Studiu de fundamentare pentru strategia națională privind reducerea sărăciei și creșterea incluziunii sociale (2015-2020). Washington (The World Bank).

TEȘLIUC, E., GRIGORAS,, V., STANCULESCU, M. S. (2016). Atlasul Zonelor Rurale Marginalizate şi al Dezvoltării Umane Locale din România. Banca Mondială, București, [Online]. Available: http://www.mmuncii.ro/j33/images/Documente/ Minister/F6 Atlas Rural RO 23Mar2016.pdf [accessed 18 September 2018].

UNION OF SERBS FROM ROMANIA (2018). [Online]. Available: http://proiecteusr.ro/? page id $=11$ [accessed December 2018].

VÂLCEANU, D., ZULAICA, L. (2012). Indicele calităţii locuirii - instrument de evaluare a calităţii locuirii urbane. Urbanism. Arhitectură. Construcţii, 3(4), 45-56. 
VÂlCEANU, D. G., TAMIRJAN, D. G. (2011). Calitatea condiţiilor de locuire în România, în perioada post-aderare la UE. Urbanism. Arhitectura. Construcţii, 3(2), 35-50.

VARADY, D. (2008). Muslim residential clustering and political radicalism. Housing Studies, 23, 45-66.

VÎRDOL, D. (2009). Dinamica social-economică a oraşelor mici din Valea Dunării Româneşti, [Online]. Available: http://www.unibuc.ro/studies/Doctorate2009 Noiembrie/Virdol\%20\%20Daniel\%20-\%20Dinamica\%20Social-[accessed September 2018]. Economica\%20a\%20Oraselor\%20Mici\%20din\%20Valea\%20Dunarii\%20Romanesti/ rezumat DanielVIRDOL.pdf [accessed 17 October 2018].

VOICU, B. (2005). Despre precaritatea locuirii urbane, în România. Calitatea Vieții, 16, 51-63.

Irena Moca nu, Bianca Mitrică, Mihaela Persu, Nicoleta Da mian

\section{SKÚMANIE VZŤAHU MEDZI ETNICKOU ŠTRUKTÚROU A KVALITOU BÝVANIA V RUMUNSKEJ ČASTI DOLINY DUNAJA}

Článok sa zameriava na vzt’ah medzi etnickými charakteristikami a rôznymi úrovňami kvality bývania v rumunskej časti doliny Dunaja. Teoretický prístup k štúdiu vzt’ahu medzi územným rozložením etnických skupín a charakteristikami ich bývania, prispôsobený miestnym osobitostiam, bol aplikovaný na špecifickú oblast' rumunskej časti Dunaja. Boli zistené dva typy lokalizácie (v jednej oblasti - napr. Turci, Srbi; vo viacerých oblastiach napr. Rómovia) a dva typy modelov identifikovaných podla distribúcie $\mathrm{v}$ rámci schémy bývania v dunajských lokalítách („výberový“ model, ktorý vyplynul z historickej a kultúrnej motivácie - napr. Česi; a „obmedzujúci“ model v dôsledku ekonomických a etnických problémov - napríklad Rómovia). Na základe tohto prístupu článok rozvíja metodiku zameranú na objasnenie vzt’ahov medzi prítomnost'ou rôznych etnických menšín a kvalitou bývania v území. Index etnickej diverzity a index kvality bývania boli vypočítané, štatisticky a územne korelované a mapované podl'a miestnych správnych jednotiek (LAU). Po súhrnnej analýze sociálno-ekonomických charakteristík a historického pozadia etnických menšín v rumunskej časti doliny Dunaja sú v časti „Výsledky a diskusia“ priblížené aspekty týkajúce sa územného rozloženia každej etnickej skupiny a kvality bývania. Autori zdôraznujú, že dve zo štatistických premenných hodnotiacich kvalitu bývania vykazujú významnú územnú koreláciu s umiestnením rôznych etnických menšín. Na záver možno povedat', že rumunská čast' doliny Dunaja predstavuje rozsiahlu oblast', v ktorej etnická rozmanitost' v dôsledku rôznych historických vplyvov je $\mathrm{v}$ tesnejšom vzt'ahu ku kvalite bývania iba $\mathrm{v}$ niektorých sídlach alebo malých vidieckych a mestských oblastiach. 